\section{unicef}

для кожної дитини

\section{БОРОТЬБА 3 COVID-19 В УКРАїHI:} початкові оцінки впливу на бідність

Наталія Бородчук ${ }^{1}$, Людмила Черенько ${ }^{2}$

15 квітня 2020 р.

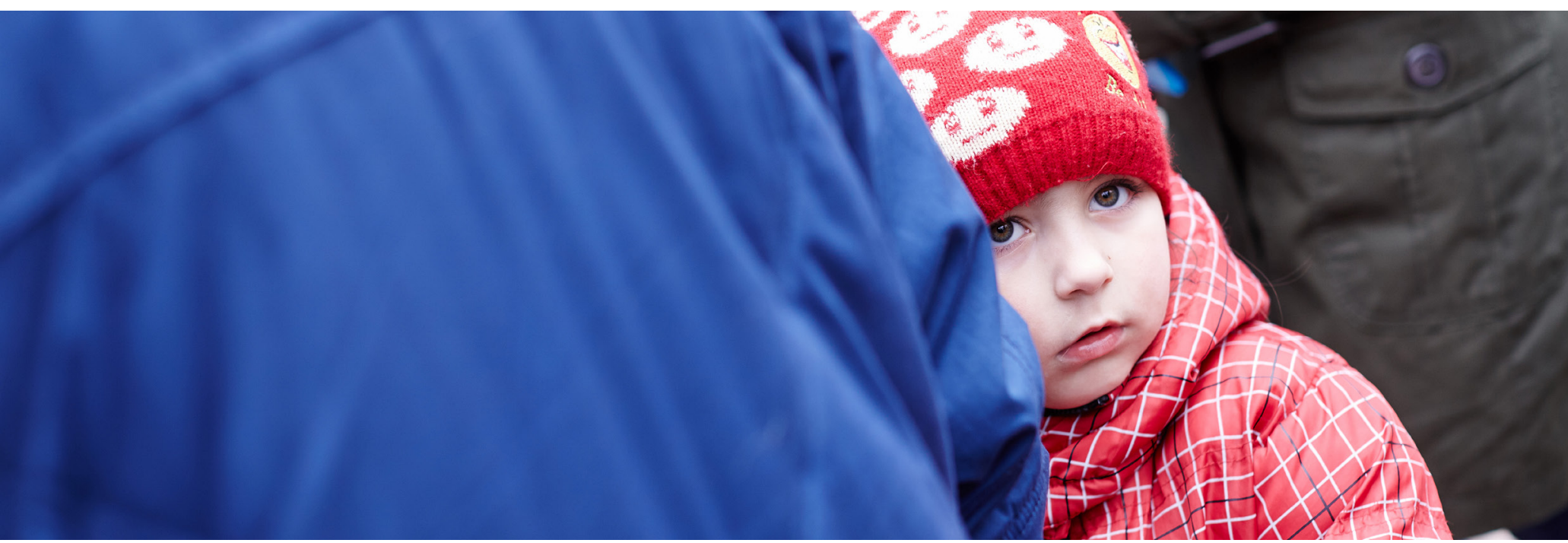

COVID-19 - унікальна криза в тому сенсі, що її соціально-економічний вплив сильно залежить від результатів реалізації стратегій щодо охорони здоров'я, подолання пандемії та карантину. Незважаючи на високий ступінь невизначеності, ми подаємо перші прогнози впливу COVID-19 на бідність, зокрема бідність дітей, і на найбільш уразливі категорії населення України. Ці результати отримані шляхом мікромоделювання на основі обстежень умов життя домогосподарств (ОУЖД). Цей звіт є “живим" документом, який регулярно оновлюватиметься в міру надходження нової інформації.

\title{
Ключові висновки
}

1. Очікується, що рівень бідності значно зросте через скорочення доходів у результаті пандемії COVID-19 за двома сценаріями:

- за менш загрозливим сценарієм (на основі останніх макропрогнозів Кабінету Міністрів України) очікується, що рівень бідності за абсолютним критерієм зросте з 27,2 до 43,6 відсотка;

- за більш загрозливим сценарієм³ очікується, що рівень бідності за абсолютним критерієм зросте з 27,2 до 50,8 відсотка.

\footnotetext{
1 ЮHICEФ, nborodchuk@unicef.org

2 Інститут демографії та соціальних досліджень, cherenko@ukr.net

Думки, висловлені в цій статті, $\epsilon$ думками авторів і не обов'язково відображають погляди ЮНІСЕФ або Інституту демографії та соціальних досліджень. ЮНІСЕФ не гарантує точності даних, наведених у цій роботі.

3 Див. деталі у технічних додатках.
} 
2. Вплив на бідність дітей, за оцінками, буде ще відчутнішим: за менш загрозливим сценарієм рівень бідності дітей за абсолютним критерієм, очікується, зросте з 32,9 до 51,3 відсотка, а за більш загрозливим сценарієм - до 58,5 відсотка.

3. За нашими оцінками, за інших рівних умов Україна може очікувати, що за менш загрозливим сценарієм кількість осіб, які живуть у бідності, збільшиться на 6,3 мільйона, включно 3 1,4 мільйона дітей, тоді як за більш загрозливим сценарієм цей показник збільшиться на 9 мільйонів, включно з 1,8 мільйона дітей.

4. У випадку більш загрозливого сценарію досягнення України щодо зменшення бідності з часів кризи 2015 року можуть бути нівельовані: Україна у цій сфері буде відкинута назад щонайменше на 3 роки.

5. У цілому найбільш уразливими з точки зору соціально-економічного впливу COVID-19 $€$ сім'ї, яким складніше диверсифікувати свої доходи.

Найбільшого впливу, скоріше за все, зазнають чотири нижченаведені категорії (у них матиме місце найбільше зростання рівня бідності порівняно з базовим сценарієм):

- домогосподарства з трьома та більше дітьми;

- одинокі батьки з дітьми;

- домогосподарства з дітьми до трьох років;

- одинокі пенсіонери старше 65 років.

6. Дуже важливо, щоб соціально-економічна політика в цей критичний час ґрунтувалася на належній доказовій базі, а обмежені ресурси використовувалися якомога ефективніше і своєчасно надавалися тим, хто найбільше потребує.

\section{1. Як COVID-19 впливає на бідність, зокрема на бідність дітей, в Україні?}

Ми оцінили потенційний вплив COVID-19 на монетарну бідність через її вплив на доходи домогосподарств. Ці прогнози базуються на останніх доступних мікроданих (за 2018 рік). Використовується національне визначення бідності за абсолютним критерієм (еквівалентні витрати нижче фактичного прожиткового мінімуму).

Ми розглядаємо два сценарії:

- менш загрозливий - на основі офіційних останніх макропрогнозів Кабінету Міністрів України (станом на 29 березня 2020 року4) і з урахуванням планів щодо підвищення пенсій (оголошених Міністерством соціальної політики);

- більш загрозливий - на основі більш песимістичних прогнозів зменшення ВВП 5 , розроблених МВФ, і впливу на ринок праці (регіональних прогнозів МОП)6.

* Детальніші дані див. у технічних додатках.

\footnotetext{
${ }^{4}$ https://www.kmu.gov.ua/npas/pro-vnesennya-zmin-do-postanovi-kabinm2903020etu-ministriv-ukrayini-vid-15-travnya-2019-r-555

5 https://www.imf.org/en/Publications/WEO/Issues/2020/04/14/weo-april-2020

${ }^{6}$ https://www.ilo.org/wcmsp5/groups/public/@dgreports/@dcomm/documents/briefingnote/wcms_740877.pdf
} 


\section{До кризи}

У 2018 році загальний рівень бідності в Україні складав 43,2 відсотка, а бідність дітей сягала 49,9 відсотка7. У 2019 році, за даними Державної служби статистики, кожний другий українець був фінансово незахищеним ${ }^{8}$. П'ятдесят один відсоток не міг собі дозволити непередбачені необхідні витрати з особистих коштів. Для порівняння: у 28 країнах Європейського Союзу (ЄС-28) цей показник дорівнював 32,5 відсотка. Крім того, кожний п'ятий українець (21,1 відсотка) не міг у повному обсязі та своєчасно оплачувати оренду, іпотеку, кредит або комунальні послуги. Для порівняння: у ЄС-28 цей показник дорівнював 8,9 відсотка.

Рис. 1. Рівень абсолютної бідності всіх домогосподарств і домогосподарств із дітьми в Україні, 2001-2018 рр.

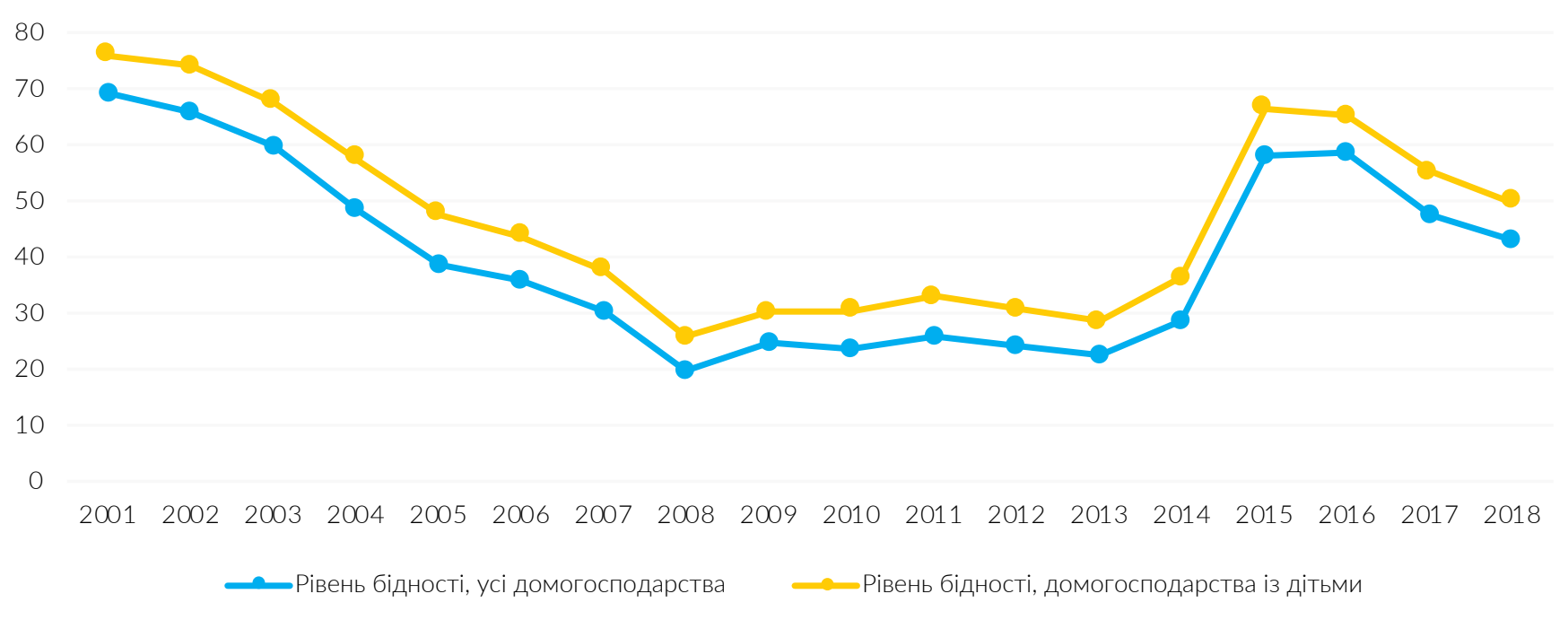

Джерело: Державна служба статистики України, ОУЖД

\section{Результати моделювання}

\section{Менш загрозливий сценарій}

(i) Згідно з менш загрозливим сценарієм очікується, що у зв'язку із COVID-19 бідність за абсолютним критерієм у 2020 році зросте на 5,8 відсоткового пункту (з 37,8 відсотка до 43,6 відсотка) порівняно з 2019 роком. Це зростання буде ще більш різким, якщо порівняти новий рівень бідності (з урахуванням COVID-19) із значенням, який можна було б очікувати у 2020 році (без COVID-19): 16,4 відсоткового пункту (з 27,2 відсотка до 43,6 відсотка).

(ii) Згідно з менш загрозливим сценарієм очікується, у зв'язку із COVID-19 бідність дітей за абсолютним критерієм у 2020 році зросте на 6,8 відсоткового пункту (з 44,5 відсотка до 51,3 відсотка) порівняно з 2019 роком. Це зростання буде ще більш різким, якщо порівняти новий рівень бідності сімей із дітьми (з урахуванням COVID-19) із значенням, який можна було б очікувати у 2020 році (без COVID-19): 18,4 відсоткового пункту (з 32,9 відсотка до 51,3 відсотка)

\footnotetext{
Еквівалентні витрати нижче фактичного прожиткового мінімуму, http://www.ukrstat.gov.ua/

в Самооцінка домогосподарствами доступності окремих товарів та послуг, 2019, http://www.ukrstat.gov.ua/
} 
Рис. 2. Рівень абсолютної бідності всіх домогосподарств і домогосподарств із дітьми в Україні, прогнози за менш загрозливим сценарієм

Менш загрозливий сценарій, всі домогосподарства

70

60

50

40

30

20

10

0

$20152016 \quad 2017 \quad 2018 \quad 2019 \quad 2020$

Без COVID

- Менш загрозливий
Менш загрозливий сценарій, домогосподарства з дітьми

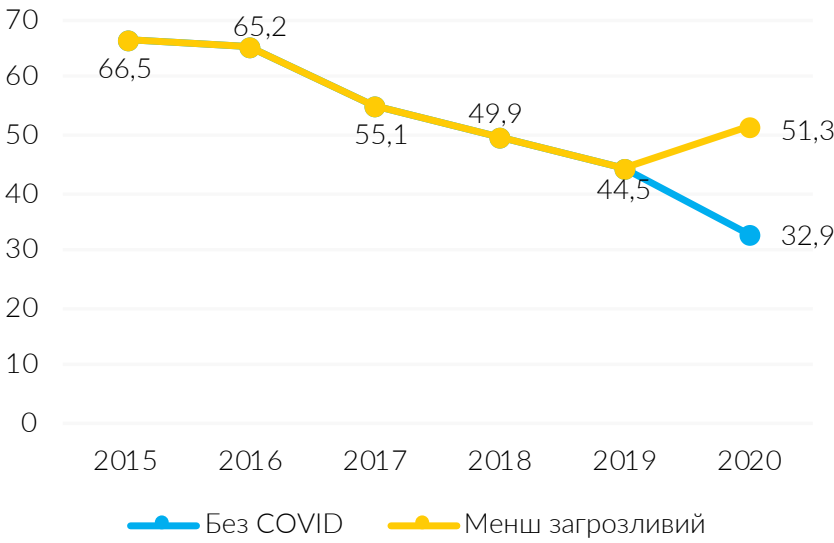

\section{Більш загрозливий сценарій}

(i) Згідно з більш загрозливим сценарієм очікується, що у зв'язку із COVID-19 бідність за абсолютним критерієм у 2020 році зросте на 13 відсоткових пунктів (з 37,8 відсотка до 50,8 відсотка) порівняно з 2019 роком. Це зростання буде ще більш різким, якщо порівняти новий рівень бідності (з урахуванням COVID-19) із значенням, який можна було 6 очікувати у 2020 році (без COVID-19): 23,6 відсоткового пункту (з 27,2 відсотка до 50,8 відсотка).

(ii) Згідно з більш загрозливим сценарієм очікується, у зв'язку із COVID-19 бідність дітей за абсолютним критерієм у 2020 році зросте на 14 відсоткових пунктів (3 44,5 відсотка до 58,5 відсотка) порівняно з 2019 роком. Це зростання буде ще більш різким, якщо порівняти новий рівень бідності сімей із дітьми (з урахуванням COVID-19) із значенням, який можна було б очікувати у 2020 році (без COVID-19): 25,6 відсоткового пункту (з 32,9 відсотка до 58,5 відсотка).

Рис. 3. Рівень бідності всіх домогосподарств і домогосподарств із дітьми в Україні, прогнози за більш загрозливим сценарієм

Більш загрозливий сценарій, всі домогосподарства

70

60

50

40

30

20

10

0

$20152016 \quad 2017 \quad 2018 \quad 2019 \quad 2020$

Без COVID

— Більш загрозливий

58,3
Більш загрозливий сценарій, домогосподарства з дітьми

70

60

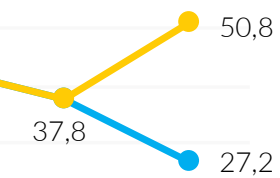

50

40

30

20

10

0

$\begin{array}{llllll}2015 & 2016 \quad 2017 & 2018 & 2019 & 2020\end{array}$

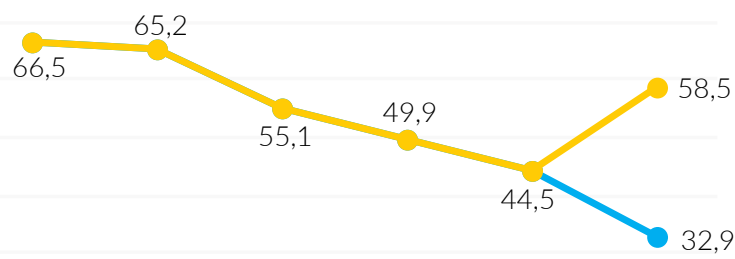

$\longrightarrow$ Без COVID — Більш загрозливий 
Табл. 1. Розрахунковий рівень бідності за абсолютним критерієм усіх домогосподарств і домогосподарств із дітьми в Україні, за сценаріями, 2018-2020 рр.

\begin{tabular}{|l|c|c|c|c|c|c|}
\hline & \multicolumn{3}{|c|}{$\begin{array}{c}\text { Рівень бідності за абсолютним } \\
\text { критерієм, усі домогосподарства, } \\
\text { у відсотках }\end{array}$} & \multicolumn{2}{|c|}{$\begin{array}{c}\text { Рівень бідності за абсолютним } \\
\text { критерієм, домогосподарства з дітьми, } \\
\text { у відсотках }\end{array}$} \\
\hline & 2018 & $2019 *$ & $2020 *$ & 2018 & $2019 *$ & $2020^{*}$ \\
\hline $\begin{array}{l}\text { Менш загрозливий } \\
\text { сценарій }\end{array}$ & 43,2 & 37,8 & 43,6 & 49,9 & 44,5 & 51,3 \\
\hline $\begin{array}{l}\text { Більш загрозливий } \\
\text { сценарій }\end{array}$ & 43,2 & 37,8 & 50,8 & 49,9 & 44,5 & 58,5 \\
\hline $\begin{array}{l}\text { Базовий сценарій } \\
\text { (без СОVID-19) }\end{array}$ & 43,2 & 37,8 & 27,2 & 49,9 & 44,5 & 32,9 \\
\hline
\end{tabular}

Джерело: оцінки авторів на основі ОУЖД, *оцінка

\section{За нашими оцінками, за інших рівних умов Україна може очікувати:}

- за менш загрозливим сценарієм кількість осіб, які живуть у бідності, збільшиться на 6,3 мільйона, в тому числі 1,4 мільйона дітей;

- за більш загрозливим сценарієм кількість осіб, які живуть у бідності, збільшиться на 9 мільйонів, в тому числі 1,8 мільйона дітей (табл. 2).

Табл. 2. Кількість осіб (зокрема дітей), які у 2020 році стануть бідними в результаті скорочення доходів (порівняно з базовим сценарієм (без COVID-19)

\begin{tabular}{|l|c|c|c|}
\hline & \multicolumn{3}{|c|}{ Кількість осіб, які стануть бідними } \\
\hline & $\begin{array}{c}\text { Усі домогосподар- } \\
\text { ства, осіб }\end{array}$ & $\begin{array}{c}\text { Домогосподарства з } \\
\text { дітьми, осіб }\end{array}$ & Діти, осіб \\
\hline Менш загрозливий сценарій & 6294000 & 3771000 & 1388000 \\
\hline Більш загрозливий сценарій & 9054000 & 5244000 & 1859000 \\
\hline
\end{tabular}

Джерело: оцінки авторів на основі ОУЖД

\section{2. Які категорії населення є новими бідними та найбільш вразливі?}

Уряд України вживає заходів із метою пом'якшення впливу пандемії та карантину на найбільш вразливі категорії населення. Перш за все, Уряд заявив про намір забезпечити безперервність усіх соціальних виплат і послуг та скоригувати порядок оформлення і виплати допомоги з урахуванням вимог щодо карантину․ Уряд запровадив разове підвищення пенсій малозабезпеченим пенсіонерам ( на 1000 грн, що складає приблизно 35 дол. США). Крім того, держава оголосила про разову виплату чинним одержувачам допомоги на дітей з інвалідністю. Запропоновано пом'якшити вимоги до участі у програмі допомоги малозабезпеченим, продовжити термін ви- 
плати й забезпечити спрощення порядку включення до цієї програми. Спрощено також порядок включення до програми субсидій на житлово-комунальні послуги, і запроваджено мораторій на стягнення пені та відключення споживачів, які оплачують комунальні послуги з затримкою ${ }^{10}$.

Враховуючи що пандемія розвивається стрімко, загальнонаціональний карантин діє та може бути продовжений, знадобляться свідчення щодо того, які групи населення є найбільш уразливими з соціально-економічної точки зору, щоб забезпечити вжиття ефективних контрзаходів у рамках реагування на ситуацію.

За нашими оцінками, COVID-19 із найбільшою імовірністю вплине на такі категорії (за менш загрозливим сценарієм): домогосподарства з трьома та більше дітьми, одинокі батьки 3 дітьми, домогосподарства з дітьми до трьох років, одинокі пенсіонери старше 65 років.

Табл. 3. Розрахунковий рівень бідності домогосподарств в Україні за абсолютним критерієм, за категоріями та сценаріями, 2019-2020 рр.

\begin{tabular}{|l|c|c|c|c|}
\hline & $2019, \%$ & $\begin{array}{c}2020 \\
\text { Базовий сценарій } \\
\text { (без COVID-19), } \\
\text { \% }\end{array}$ & $\begin{array}{c}2020 \\
\text { Менш } \\
\text { загрозливий } \\
\text { сценарій, \% }\end{array}$ & $\begin{array}{c}\text { Різниця між ба- } \\
\text { зовим сценарієм } \\
\text { і менш загрозли- } \\
\text { вим сценарієм на } \\
\text { 2020 р., в.п. }\end{array}$ \\
\hline Домогосподарства з дітьми & 44,5 & 32,9 & 51,3 & 18,4 \\
\hline Домогосподарства без дітей & 30,2 & 20,6 & 34,7 & 14,1 \\
\hline $\begin{array}{l}\text { Один дорослий молодше 65 } \\
\text { років }\end{array}$ & 18,5 & 15,9 & 24,6 & 8,7 \\
\hline $\begin{array}{l}\text { Один дорослий старше 65 } \\
\text { років }\end{array}$ & 32,0 & 31,8 & 45,6 & 13,8 \\
\hline Один дорослий з дітьми & 42,1 & 32,7 & 71,3 & 38,6 \\
\hline $\begin{array}{l}\text { Домогосподарства з дітьми } \\
\text { до 3 років }\end{array}$ & 51,1 & 43,3 & 62,6 & 19,3 \\
\hline $\begin{array}{l}\text { Домогосподарства з трьома } \\
\text { та більше дітьми }\end{array}$ & 63,8 & 49,0 & 70,6 & 21,6 \\
\hline Разом по Україні & 37,8 & 27,2 & 43,6 & 16,4 \\
\hline
\end{tabular}

Для вироблення політики дуже важливо розуміти, яку частку найбільш уразливі категорії складають серед "нових" (додаткових) бідних (табл. 4).

Табл. 4. Частка домогосподарств усіх нових (додаткових) бідних за категоріями, \%

\begin{tabular}{|l|c|}
\hline \multicolumn{1}{|c|}{ Групи домогосподарств } & Частка всіх нових (додаткових) бідних, \% \\
\hline Домогосподарства з дітьми & 59,9 \\
\hline Домогосподарства без дітей & 40,1 \\
\hline Один дорослий старше 65 років & 3,4 \\
\hline
\end{tabular}

${ }^{10} \mathrm{http} / / /$ www.ugogentilini.net/wp-content/uploads/2020/04/Country-SP-COVID-responses_April10.pdf; https://www.imf.org/en/Topics/imf-and-covid19/Policy-Responses-to-COVID-19\#U 


\begin{tabular}{|l|c|}
\hline \multicolumn{1}{|c|}{ Групи домогосподарств } & Частка всіх нових (додаткових) бідних, \% \\
\hline Один дорослий з дітьми & 5,5 \\
\hline Домогосподарства з дітьми до 3 років & 13,1 \\
\hline Домогосподарства з трьома та більше дітьми & 3,2 \\
\hline Нові (додаткові) бідні & $\mathbf{1 0 0 \%}$ \\
\hline
\end{tabular}

\section{Висновки}

В Україні пандемія COVID-19 стала реальним викликом не лише як криза в галузі здоров'я населення, а й як соціально-економічна криза через її вплив на бідність, зокрема бідність дітей. COVID-19 загрожує також здатності України досягти Цілей сталого розвитку. Для того, щоб забезпечити використання дефіцитних ресурсів із найбільшою користю та охопити нужденних, дуже важливо мати дані про те, як COVID-19, за очікуваннями, вплине на бідність і які групи населення будуть найбільш уразливими. Сподіваємося, що результати цього мікромоделювання ляжуть в основу соціально-економічної політики Уряду України та сформують напрямки програмної роботи ключових зацікавлених сторін.

Аналіз демонструє, що за обома сценаріями рівні бідності значно зростуть у результаті карантинних заходів у зв'язку з COVID-19, причому бідність дітей зросте ще різкіше. У цілому найбільш уразливими з точки зору соціально-економічного впливу COVID-19 є сім'ї, які не можуть диверсифікувати свої доходи. Сім'ї з обома батьками та сім'ї, що складаються з представників кількох поколінь, з більшою імовірністю компенсуватимуть зменшення чи втрату доходу одного члена сім'ї доходом або соціальною допомогою, що збереглися в інших членів сім'ї. 3 іншого боку, нижчезазначені категорії більш залежні від єдиного джерела доходу і 3 більшою імовірністю стануть бідними в результаті COVID-19: одинокі батьки з дітьми, домогосподарства з дітьми до 3 років, та одинокі пенсіонери старше 65 років, а також сім'ї з трьома та більше дітьми, серед яких традиційно спостерігаються найвищі рівні бідності. У цій публікації представлено оцінки масштабу цього впливу.

Таким чином, заходи соціального захисту, спрямовані на пом'якшення наслідків COVID-19, повинні мати комплексний характер і передбачати використання інструментів і програм, які зараз є у розпорядженні Міністерства соціальної політики та інших профільних міністерств. Замість того, щоб застосовувати підхід, оснований на категоріях, необхідно використати комбінацію кількох інструментів і програм, як універсальних, так і адресних, для охоплення найбільш уразливих категорій (наприклад, допомоги у зв'язку з народженням дитини, допомоги малозабезпеченим, допомоги багатодітним сім'ям, допомоги одиноким батькам).

\section{Технічні додатки}

\section{Додаток 1. Припущення}

Наші оцінки сильно залежать від терміну дії карантинних заходів. У цих початкових прогнозах ми припускаємо, що карантин триватиме три місяці (березень-травень), після чого відновиться економічна активність. На момент підготовки цього матеріалу офіційно оголошено, що карантин в Україні триватиме з 12 березня до 24 квітня (з можливістю продовження). 
Як базовий сценарій на 2020 рік (без COVID-19) ми беремо такі показники: середнє значення прогнозів ВВП на 2020 рік, зроблених до кризи - 103,5 відсотка (середнє значення прогнозів Кабінету Міністрів, Світового банку і МВФ11); рівень інфляції - 105 відсотків (Національний банк України ${ }^{12}$ ); мінімальна заробітна плата - 4723 грн (Державний бюджет України ${ }^{13}$ ); мінімальна пенсія - 1676 грн, хронологічне середнє прожиткового мінімуму для пенсіонерів, що коригується тричі на рік (Державний бюджет України); середня номінальна заробітна плата - 12043 грн (реальна - 11440 грн); середня пенсія та інші доходи - зростання відповідно до прогнозів ВВП (103,5 відсотка).

У якості менш загрозливого сценарію (з урахуванням COVID-19) ми беремо офіційні прогнози Кабінету Міністрів (на 30 березня ${ }^{14}$ ): ВВП - мінус 4,8 відсотка, або 95,2 відсотка; інфляція 111,6 відсотка; мінімальна заробітна плата - 4723 грн (Державний бюджет України); мінімальна пенсія - хронологічне середнє (Державний бюджет України), 1676 грн; середня номінальна пенсія - 106 відсотків (Міністерство соціальної політики) 15; середня номінальна заробітна плата - 10700 грн; інші доходи - з урахуванням зниження ВВП до 95,2 відсотка та інфляції 111,6 відсотка - 106,2 відсотка (номінальні).

Ми робимо певні припущення щодо впливу COVID-19 на доходи домогосподарств, інакше кажучи - ми припускаємо, що різні групи, скоріше за все, зазнаватимуть різного впливу в результаті кризи. На основі експертної оцінки, для осіб, які потенційно могли б зазнати сильнішого впливу, ми застосовуємо інші (нижчі) коефіцієнти. Ми враховуємо заходи реагування в галузі соціальної політики, як-от підвищення пенсій у другому півріччі 2020 року.

Як більш загрозливий сценарій (з урахуванням COVID-19) ми беремо такі цифри прогноз ВВП на 2020 рік - мінус 7,7 відсотка, або 92,3 відсотка (прогноз МВФ)16; інфляція - 111,6 відсотка (Кабінет Міністрів України); мінімальна заробітна плата - 4723 грн (Державний бюджет України); мінімальна пенсія - хронологічне середнє (Державний бюджет України), 1676 грн; середня номінальна пенсія - 102.9 відсотка ${ }^{17}$; всі доходи від трудової діяльності (крім заробітної плати на рівні мінімальної та нижче мінімальної) - зменшення у номінальному виразі на 6 відсотків (прогнози МОП для даного регіону ${ }^{18}$ ).

\section{Додаток 2. Обмеження}

По-перше, ми не враховуємо інші потенційні механізми впливу пандемії на бідність. По-друге, усвідомлюючи, що бідність - багатовимірне явище, у цьому аналізі ми все ж оцінюємо тільки вплив на монетарну бідність. По-третє, ми враховуємо лише деякі контрзаходи соціальної політики (підвищення пенсій), не беручи до уваги інші (наприклад, збільшення допомоги по безробіттю), які могли б певною мірою ослабити вплив пандемії.

\footnotetext{
${ }^{11}$ https://minfin.com.ua/2019/10/23/39477102 ; https://www.worldbank.org/en/news/press-release/2020/01/08/modest-pickup-in-2020amid-mounting-debt-and-slowing-productivity-growth; https://interfax.com.ua/news/economic/618981.html

12 https://bank.gov.ua/news/all/natsionalniy-bank-zberig-prognoz-inflyatsiyi-na-2019-2021-roki-i-polipshiv-otsinku-zrostannya-ekonomiki-7024

13 https://zakon.rada.gov.ua/laws/show/294-IX

${ }^{14}$ https://www.kmu.gov.ua/npas/pro-vnesennya-zmin-do-postanovi-kabinm2903020etu-ministriv-ukrayini-vid-15-travnya-2019-r-555

${ }^{15}$ https://www.ukrinform.ua/rubric-economy/2902457-v-ukraini-z-travna-trudovi-pensii-proindeksuut-na-11.html / Як заявила Міністр coціальної політики М. Лазебна, починаючи з травня вводиться індексація на 11\% (у річному вимірі - підвищення на 6\%).

${ }^{16}$ https://www.imf.org/en/Publications/WEO/Issues/2020/04/14/weo-april-2020

17 Реальний ВВП - 92,2\%, ураховуючи інфляцію 111,6\%, номінальний - 102,9\%.

${ }^{18}$ https://www.ilo.org/wcmsp5/groups/public/@dgreports/@dcomm/documents/briefingnote/wcms_740877.pdf
} 